Thomas Wallnig, Marion Romberg, Joëlle Weis (Hg.)

\title{
Achtzehntes Jahrhundert digital: zentraleuropäische Perspektiven
}

\section{Digital Eighteenth Century: Central European Perspectives}

\section{Dix-huitième siècle numérique: perspectives de l’Europe centrale}

Unter Mitarbeit von Sandra Hertel

BÖHLAU VERLAG WIEN KÖLN WEIMAR 
Das Jahrbuch wird von Vorstand und Beirat der OGE18 herausgegeben. Die Geschäftsführung liegt beim Obmann.

Gedruckt mit freundlicher Unterstützung der Historisch-Kulturwissenschaftlichen Fakultät der Universität Wien, des Instituts für Geschichte der Universität Luxemburg, der OeAD-GmbH (aus Mitteln des Bundesministeriums für Europa, Integration und Äußeres) sowie der Stadt Wien.
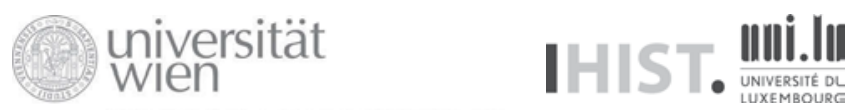

œeaD" Historisch-Kulturwissenschaftliche Fakultä!

\section{KUIENTR}

Bibliografische Information der Deutschen Nationalbibliothek :

Die Deutsche Nationalbibliothek verzeichnet diese Publikation in der

Deutschen Nationalbibliografie ; detaillierte bibliografische Daten

sind im Internet über http://dnb.d-nb.de abrufbar.

Umschlagabbildung : Johann Samuel Wahl, Elisabeth Christine und Karl VI. beim Hochzeitsmahl Maria Theresias. Digitale Bildbearbeitung (nach einer gemeinfreien Kopie): Joëlle Weis.

() 2019 by Böhlau Verlag Ges.m.b.H \& Co. KG, Wien, Kölblgasse 8-10, A-1030 Wien Alle Rechte vorbehalten. Das Werk und seine Teile sind urheberrechtlich geschützt. Jede Verwertung in anderen als den gesetzlich zugelassenen Fällen bedarf der vorherigen schriftlichen Einwilligung des Verlages.

Einbandgestaltung : Michael Haderer, Wien

\section{Vandenhoeck \& Ruprecht Verlage | www.vandenhoeck-ruprecht-verlage.com}




\section{Contents}

\section{Thomas Wallnig}

About This Volume

\section{Articles}

\section{Mikkel Munthe Jensen, Marco Quaggiotto, Joëlle Weis}

VIA - Virtual Itineraries of Academics - A Digital Exploration

Tool for Early Modern Academic Travels

\section{Marion Romberg}

Maps, Timelines, Search Features, and Indices - Digital Tools in the Continent Allegories Database.

\section{Claudia Resch, Dario Kampkaspar}

DIGITARIUM - Unlocking the Treasure Trove of $18^{\text {th }}$-Century

Newspapers for Digital Times

\section{Per Pippin Aspaas, Katalin Pataki}

Did Astronomy Constitute a Denominationally Neutral Space within the Republic of Letters? - An Outline for the Use of

Visualization Tools in the Study of Astronomical Correspondence

\section{Jonathan Singerton}

A Revolution in Ink - Mapping Benjamin Franklin's Epistolary

Network in the Habsburg Monarchy, 1776-1789

Short Papers and Project Presentations

\section{Stefan Ehrenpreis}

Big Data and the History of Early Modern Individuals - The Case of VOC Employees from the Habsburg Territories

\section{Doris Gruber, Elisabeth Lobenwein, Arno Strohmeyer}

Travelogues - Perceptions of the Other 1500-1876.

A Computerized Analysis.... 


\section{Anna Frasca-Rath}

Research Landscapes of Digital Art History in Austria

\section{Karin Schneider, Stephan Kurz}

https://maechtekongresse.acdh.oeaw.ac.at/ - Digital Edition of the

Documents of the Congresses of Aix-la-Chapelle,

Troppau/Opava, Laibach/Ljubljana and Verona 1818-1822

\section{Patrick Fiska}

Conference Report: Digitizing Enlightenment III

\section{Klemens Kaps, Kolja Lichy}

Conference Report: The Four Wings of Mercury 153

\section{Book Reviews}

Olga Katsiardi-Hering / Maria A. Stassinopoulou (Eds.):

Across the Danube. Southeastern Europeans and Their Travelling Identities $\left(17^{\text {th }}-19^{\text {th }}\right.$ c.) (Harald Heppner)

Marianne ACQUARELLI: Die Ausbildung der Wundärzte in Niederösterreich. Unter der Herrschaft der Habsburger vom 18. bis zum 19. Jahrhundert (Sonia Horn) 170

Markwart Herzog / Alois Schmid (Hg.): Katholische Aufklärung im Benediktinerreichsstift Irsee (Manuela Mayer)

Karen Green: A History of Women's Political Thought in Europe, 1700-1800 (Jonathan Singerton) 178

Renate Zedinger / Marlies Raffler / Harald Heppner (Hg.): Habsburger unterwegs. Vom barocken Pomp bis zur smarten Businesstour (Renate Schreiber)

Buchreihe „Veröffentlichungen zur Bau- und Funktionsgeschichte der Wiener Hofburg" (Sandra Hertel)

Zusammenfassungen und Abstracts 


\section{Did Astronomy Constitute a Denominationally Neutral Space within the Republic of Letters?}

\section{An Outline for the Use of Visualization Tools in the Study of Astronomical Correspondence}

\section{Disclaimer ${ }^{1}$}

"This article is a stub". This quote, which should be familiar to anyone who, during an Internet search, has come across a Wikipedia page presenting insufficiently documented information, may not seem like a promising starting point for a research article. Much of what is published within the field of Digital Humanities (DH), however, is precisely that: insufficiently documented. This article is no exception. It is an experiment-or more precisely an attempt to present an outline for the use of visualization tools in the study of astronomical correspondences. Essentially, it represents a big data approach applied to a much too small dataset. You can help the Digital Humanities community by expanding it.

\section{What's in a Map?}

Letters are small, uniform units carrying information about interactions between people of the past. Extracting basic metadata (letter written by person $x$ at location $a$, addressed to person $y$ at location $b$, dated day-month-year) and inserting this information into a tabular overview is as straightforward and well-established a method as it is a powerful and indispensable one. It can

1 The idea for this article was first discussed with Thomas Wallnig (Vienna) in the context of a European COST Action programme that he chaired together with Howard Hotson (Oxford): "Reassembling the Republic of Letters, 1500-1800" http://www.republicofletters.net/, accessed 22.01.2019. We thank Thomas and the rest of the editorial team of this issue of Das Achtzehnte Jahrhundert und Österreich, and in particular the anonymous peer reviewer, for numerous suggestions for improvement of our manuscript. We also thank László Kontler (Budapest) and Helene N. Andreassen (Tromsø) for moral support and fruitful discussions; the DARIAH-DE helpdesk team, the organizers and lecturers of the ReIReS Digital Humanities courses held in Mainz, and the Dataverse.no team of UiT The Arctic University of Norway for technical guidance. 
also be an excellent basis for further investigation. Tools that summarize such information visually and provide an easily accessible overview can open up new fields of inquiry. Graphs depicting networks as well as maps tracing the correspondence of persons of the past have often been used as illustrations in the traditional formats of scholarship. Such maps have apparently also often been considered dispensable, however-a kind of supplementary material that may or may not be produced and added at the very last stage before a publication like a biography is put to print. In the field of Digital Humanities, it is becoming increasingly common to reverse this process: In many recent projects, visualizations of correspondence networks no longer simply serve as illustrations, showing the reader in a condensed fashion what hundreds of words already spell out in detail in the main text of a publication. Rather, visualizations have become heuristic tools for scholars in their own right.

As the production of sophisticated, flexible maps becomes part of the workflow throughout the research process, it can also increase the need to (re-)read the traditional sources with a higher sensitivity to pieces of information that refer to spatial relations and draw the attention of researchers to metadata referring to geographical location. In fortunate cases, the mapping process can generate a dialogue between traditional, text-centred inquiries and computational methods based on geographical and numerical data. In the latter approach, the results are communicated more easily and efficiently with the help of visualisation tools. However, they can also require a different set of skills from the researcher as well as the reader to evaluate and interpret them.

It is the aim of this article to explore the possibilities and limitations of visualizations based on the metadata of correspondences. Our test case is that of Habsburg astronomers witnessing the dissolution of the Society of Jesus in 1773. While the ideologically charged discourse about-and gradual suppression of-Jesuits in Catholic Europe went on for more than two decades, the papal bull Dominus ac Redemptor noster of July 1773 dealt a dramatic blow to the order in the Habsburg territories. The Jesuits were not the only monastic order targeted by these reforms, but they were the first to face complete abolition and the takeover of their houses and schools by the state.

By investigating the correspondences of three Habsburg astronomers, each of whom was active in the profession at least a decade before and after 1773, we hope to shed light on the opportunities offered by maps as compared to a) crude tabular overviews of correspondence metadata and b) more traditional, non-DH approaches.

The creation of the maps presented in this article was not merely restricted to rendering a visual representation of certain geographical data. It was also motivated by the ambition to create maps on the basis of the available data. Finding suitable digital tools for communicating these ideas was necessary 
not only for the sake of the readers of the article, but to enable the authors themselves to collaborate efficiently. Besides the commonly known options provided by Google Maps, the newly developed tools for Digital Humanities such as DARIAH-DE Geo-Browser and Palladio ${ }^{2}$ proved to be helpful for creating online-accessible maps that can be used dynamically-unlike maps confined by the limitations of a "frozen" printed image-by zooming in and out, scaling symbols according to various variables or linking geographical data with a timeline. The map views presented in this article were created using QGIS in accordance with the requirements and limitations that printed maps are forced to comply with.

Using such a variety of tools also made it necessary to clean and reshape the datasets. In this regard, the standards required by DARIAH-DE Geo-Browser and Palladio were instructive not only for creating datasets that are reusable in multiple ways for the actual project, but also for complying with the FAIR data principles ${ }^{3}$ intended to facilitate long-term usability of data by ensuring that they can be easily exchanged, amended or contrasted with the results of other researchers.

The astronomers we selected, namely two Jesuits and one Benedictine, experienced the dissolution of the Society of Jesus in 1773 at a point when they were at the height of their careers. It was our goal to determine whether this dramatic event constituted a watershed in their professional careers in terms of the number of letters exchanged with peers at other observatories. In undertaking our analysis, we first produced tabular overviews of what remains of their correspondences, then constructed several maps based on this information. In the tabular overviews, correspondents are listed according to religious affiliation (denomination). The quantity of letters exchanged with peers at different locations before and after 1773 is highlighted both in the tabular overviews and the accompanying maps. Rather than proceeding in medias res, however, a brief introduction to the eighteenth-century "Republic of Astronomers" and the specific importance of transdenominational correspondence for this community seems warranted.

2 Palladio was constructed by the Mapping the Republic of Letters project at Stanford in keeping with the overall aim of developing "a general-purpose suite of visualization and analytical tools" for the examination of "scholarly communities and networks of knowledge during the period 1500-1800", see http://hdlab.stanford.edu/palladio/about/, accessed 22.01.2019. Geo-Browser was developed by the Staats- und Universitätsbibliothek Göttingen in collaboration with other partners of the DARIAH-DE project. It aims to provide "researchers of the humanities and cultural sciences" with a tool "for the analysis of space-time relations of data", see https://de. dariah.eu/geobrowser, accessed 22.01.2019.

3 FAIR = Findable, Accessible, Interoperable, Reusable. See https://libereurope.eu/wp-content/ uploads/2017/12/LIBER-FAIR-Data.pdf, accessed 22.01.2019. 


\section{The Republic of Astronomers}

The notion of a respublica litteraria or Republic of Letters was a commonplace in early modern science. According to the concept, scholars were to put aside all political, cultural and theological antagonisms and engage in an empiricallybased, mutually beneficial pursuit of knowledge. And although there may have been some divergence between ideal and reality, there can be no doubt that the concept and its accompanying associations helped to create a common identity among men of learning. As an "imagined community", the Republic of Letters assembled "intellectual citizens" across political, cultural and confessional boundaries and allowed them to engage in a fruitful exchange of scientific ideas and empirical results. ${ }^{4}$ A subdivision of this larger republic of the learned was the respublica astronomica or "Republic of Astronomers". 5 During the seventeenth century, astronomy had been marked by a series of ground-breaking theories that were often based on observations made by a single observer in an isolated observatory. Kepler's calculations, for example, were based almost exclusively upon the observations of Tycho Brahe. By contrast, eighteenth-century astronomy was characterized by the operationalization of the theories of Kepler, Newton and Leibniz as scientific practice. The century of enlightenment saw the appearance of a steadily growing number of observatories equipped with standardized instruments and populated by observers that collaborated transnationally_and transconfessionally_on a scale that would have been impossible before. ${ }^{6}$

4 For further reading, see for example Lorraine Daston, The Ideal and Reality of the Republic of Letters in the Enlightenment. In: Science in Context 4 (1991), 367-386; Hans Bots / Françoise Waquet, La République des Lettres, Paris 1997; Dirk van Miert / Howard Hotson / Thomas Wallnig. What was the Republic of Letters?, in: Howard Hotson / Thomas Wallnig (eds.), Reassembling the Republic of Letters in the Digital Age. Standards, Systems, Scholarship. Göttingen 2019, 21-38.

5 The term appears to have been widely used not just by the astronomers themselves, but also in non-specialist journals reviewing their work. See e.g. the review of Johann III Bernoulli's Liste des astronomes connus, actuellement vivans. In: Gazette littéraire de l'Europe 76:2 (November 1776), 446-449 ("République Astronomique"); or the review of Hell's edition of Szerdahely's poem Elegia epidictica, per quam demonstratur: Primum hominem Adamum fuisse primum et maximum Astronomum. In: Oberdeutsche, allgemeine Litteraturzeitung 3:129 (29 October 1790), 825-826 ("Respublica Astronomica").

6 The rapid growth in institutionalized astronomy is evident from Johannes WeIDLER, De Praesenti Specularum Astronomicarum Statu Dissertatio. Wittenberg 1727 (describing sixteen European observatories) and Jerôme de LALANDE, Des différens observatoires de l'Europe, in: Astronomie, $3^{\text {rd }}$ ed. Paris 1792, xxx-liv (describing 138 observatories). 
Eighteenth-century astronomy has been described as a scientific discipline "avant la lettre". The notion of a scientific discipline as entailed by the "functional differentiation" or breakdown of the interdisciplinary nature of the Republic of Letters that took place during the nineteenth century presupposes several constituting elements. Among these are the development of a (separate) professional identity, establishment of (separate) publication venues, and agreement on a (separate) set of modi operandi. In contrast to most other branches of science, all these elements are clearly distinguishable in eighteenth-century astronomy. This can be explained in part by intrinsic factors within astronomy as a research activity, and in part by sociocultural factors such as the emergence of a secular work ethic in which theological and ideological concerns were increasingly marginalized.

Collaboration was the sine qua non of eighteenth-century astronomy. In order to test new instruments and observational procedures, determine longitudes, and calculate the trajectories of planets and comets etc., the widespread exchange of "corresponding observations" (i.e. simultaneous observation of the same phenomenon from different locations $)^{8}$ became essential-since it was the only means by which progress in the (proto)discipline could be achieved. This aspect was not only innate in the immense enterprise of calculating the distance between the Sun and the Earth, and indeed the scale of the entire solar system, by means of simultaneous observations of the transits of Venus in front of the disc of the Sun in 1761 and 1769. It was also a key feature in the painstaking establishment of geographical coordinates, e.g. the ongoing collaborative efforts to determine the longitude of observatories with ever greater precision based on meticulous observations of occultations of the moons of Jupiter as well as solar and lunar eclipses. Such activity was indisputably the task of astronomers-and its results were increasingly being published in journals devoted to astronomy in which the observational procedures or astronomical methods were either taken for granted or (in the event that novel methods or instruments had been used) described in detail.

Over the course of the early modern era, astronomical inquiry became more and more detached from theological questions. By the middle of the eighteenth century, controversies of the kind associated with the trial of Galileo Galilei and the ban on heliocentric theory had either petered out altogether or been swept under the carpet of civility. Jesuits, Benedictines, Lutherans, Anglicans

7 Irène Passeron, La République des Sciences. Réseaux des correspondances, des académies et des livres scientifiques, in: Dix-huitième siècle 40 (2008), 20.

8 For a succinct discussion of this term, see Peter BRosche, Korrespondierende Beobachtungen. In: Ingrid KästNER (ed.), Wissenschaftskommunikation in Europa im 18. und 19. Jahrhundert. Aachen 2009, 95-99. 
and Calvinists all appeared to agree on basic research methods involving longdistance collegial collaboration. With the removal of Copernicus from the index librorum prohibitorum in 1758 , the secularization of astronomy had reached its symbolical zenith.

While this story may be familiar to historians of the described epoch of astronomy, there are nevertheless nuances left to explore. One question that has rarely been raised, for example, is to what extent individual astronomers crossed denominational borders in their pursuit of corresponding observations. In particular, it appears worthwhile to examine more closely the nature of the "ecosystem" of corresponding observations during periods when it was seriously challenged by external factors-as was the case following the highly politicized suppression of the Society of Jesus in 1773.

\section{Three Habsburg Astronomers}

By 1773 , astronomy was a well-established specialty of the Jesuits in the socalled Provincia Austriae (or Austriaca). This "Austrian province" encompassed not only modern-day Austria, but all of Hungary and Slovakia along with parts of countries now known as Romania, Croatia, Slovenia and (north-eastern) Italy as well. ${ }^{9}$ Beginning in the 1730 s, the Jesuits founded a total of five observatories within the province: Two were established in Vienna (one attached to the Jesuit college of the University of Vienna and built in 1733-34, the other-the Imperial-Royal Observatory-built on top of the assembly hall of the university in 1755-56), one in Graz/Graecium (at the university campus, constructed in 1745), one in Trnava/Tyrnau/Nagyszombat/Tyrnavia (at the Jesuit university, constructed in 1753-55), and one in Cluj/Klausenburg/Kolozsvár/Claudiopolis (at the Jesuit university, constructions begun in 1753, but apparently never completed). ${ }^{10}$ At all of these institutions, Jesuit professors of mathematics, physics or astronomy were put in charge of instruments and programmes for observing the sky; students assisted in observations as part of their education in applied mathematics.

Habsburg astronomers of other religious affiliations were few and far between, with the Benedictines forming a notable exception. The observatory of the Bene-

9 For a contemporaneous map, see Matthaeus Seutter, Provincia Austriaca Societatis Iesu. No place, no date (c. 1727-1730). Digitized by Bibliothèque nationale de France: https://gallica. bnf.fr/ark:/12148/btv1b530412764. Digitized by Moravská zemská knihovna v Brně: http:// mapy.mzk.cz/mzk03/001/052/234/2619316430, accessed 22.02.2019.

10 Per Pippin Aspaas / Thomas Posch / Isolde Müller / Ákos Bazsó, Astronomische Observatorien der Jesuiten in der "Provincia Austriae" im 18. Jahrhundert. In: Acta Historica Astronomiae 52 (2014), 89-110. 
dictine monastery in Kremsmünster/Cremifanum (opened in 1758) was by far their most important site for astronomical research. Some two decades later, a smaller observatory was established at the monastery of Lambach/Lambacum (constructed 1777). In the meantime, however, the Society of Jesus had ceased to exist. The Jesuit observatories in Vienna (the one located at the Jesuit college), Graz and Cluj were all soon abandoned and their staff reassigned. In Trnava, the former Jesuit observatory persisted until 1785, when it was abandoned for good. Meanwhile, in accordance with a royal decree, the main university on Hungarian soil had been moved to present-day Budapest, with a new observatory run by former Jesuit professors dislocated from Trnava opened there in 1778. Throughout this entire time, however, the Imperial-Royal Observatory in Vienna continued its activities unabated.

In our present study, we are investigating three Central European astronomers: Maximilian Hell SJ (1720-1792), director of the Imperial-Royal Observatory in Vienna from 1755 to 1792, Ferenc Weiss SJ (1717-1785), director of the university observatory in Trnava and Pest/Buda from its opening in 1755 until 1785, and Placidus Fixlmillner OSB (1721-1791), director of the observatory of the monastery in Kremsmünster from 1762 (a few years after its establishment) until his death in 1791 . All three were widely connected and maintained direct contact with colleagues both within the Habsburg Monarchy and beyond. Two of the men, Hell and Fixlmillner, have been referred to as the "founders of modern astronomy in Austria", ${ }^{11}$ and the role of Weiss in the Hungarian part of the monarchy was no less constitutive. ${ }^{12}$ Within our research project, the preserved correspondence of the Benedictine Fixlmillner and the two Jesuits Hell and Weiss is separated into letters written before and after July 1773 in the tabular overview shown below as well as visually in the map view.

The radical, reform-oriented ideology propagated by Emperor Joseph II may have made their own status questionable and the prospects of their observatories more precarious, but Hell and Weiss nevertheless continued their professional careers as university professors until their deaths. In his position as abbot of the Benedictine monastery of Kremsmünster, Fixlmillner appears not to have been noticeably affected; his abbey remained an autonomous religious entity throughout the tumultuous times of incisive educational and cultural reforms. On the surface, all three men were thus protected from the fundamental reworking of the landscape of learning and education in the Habsburg lands

11 Konradin Ferrari d’Ochieppo, Maximilian Hell und Placidus Fixlmillner. Die Begründer der neueren Astronomie in Österreich. In: Fritz KnolL (ed.), Österreichische Naturforscher, Ärzte und Techniker. Vienna 1957, 27-32.

12 Magda Vargha, Correspondence de Ferenc Weiss astronome hongrois du XVIIIe siècle. 2 vols. Budapest 1990-1992. 
during the latter years of the fourty-year reign of Maria Theresa and the decade of Emperor Joseph II. ${ }^{13}$

From the very beginnings of their careers, the three astronomers that we selected for scrutiny played different roles: Hell was a representative of the university (as professor) and of the court (as Imperial-Royal Astronomer). Upon his appointment as the latter in 1755 , he was assigned several tasks including the following: ${ }^{14}$

In order to promote the honor of this capital and its university, and to steer it towards the common good, the Imperial and Royal Astronomer shall maintain a perpetual scientific correspondence (Commercium litterarium) with all the famous observatories abroad, and in so doing make sure that all observations that are necessary for the advancement of geography be communicated to this observatory by the foreign ones, and that no observations of the kind that other astronomers are eager to receive, shall be neglected by him.

Hell did not ignore this instruction. Moreover, in his role as editor of Vienna's official, large-format almanac-the Ephemerides ad Meridianum Vindobonensem-he also seized the opportunity to establish what would effectively become an astronomical journal in its own right. Added to each volume were supplements containing a variety of treatises and reports on astronomy, optics and geophysics that regularly filled more than a hundred quarto pages. The Ephemerides are testimony to Hell's far-reaching network within the Republic of Letters, ${ }^{15}$ but his correspondence has unfortunately survived only in parts.

13 These processes cannot be described in full detail here. For further reading on the antimonastic measures taken by the Viennese administration in the latter half of the eighteenth century, see for example Gerhard WinNER, Die Klosteraufhebungen in Niederösterreich und Wien. Vienna - Munich, 1967; Peter Hersche, Der Spätjansenismus in Österreich. Vienna 1977; Derek Edward Dawson Beales, Prosperity and Plunder. European Catholic Monasteries in the Age of Revolution, 1650-1815. Cambridge - New York 2003, esp. 143-168, 179-228. Dickson, P. (1993). Joseph II's Reshaping of the Austrian Church. The Historical Journal, 36(1), 89-114. doi:10.1017/S0018246X00016125. On the plight of Jesuit astronomers from the Provincia Austriae in particular, see Per Pippin AsPaAs, Maximilianus Hell (1720-1792) and the Eighteenth-Century Transits of Venus. A Study of Jesuit Science in Nordic and Central European Contexts. Diss. Tromsø 2012, 84-95, 162-177. http://hdl.handle.net/10037/4178, accessed 22.02.2019.

14 Ernennung Maximilian Hells zum k.k. Astronomen. Beilage: Instruction. Für den Kaiser. Königl. Astronomen Maximilianum Hell S.J. Universitätsarchiv Wien, Universitätskonsistorium, CA 1.2.102. English translation in: Per Pippin AspaAs / László Kontler, Maximilian Hell (1720-1792) and the Ends of Jesuit Science in Enlightenment Europe. Leiden - Boston (forthcoming).

15 For a bibliographic overview, see Carlos Sommervogel, Hell, Maximilien. In: Bibliothèque de la Compagnie de Jésus [...] Bibliographie. Tome IV. Brussels - Paris 1893, 238-258. On 
For this article, we had access to 91 letters addressed to Hell as well as 259 letters written by him. We have not included letters printed in the Ephemerides or included as letters to the editors in the Journal des Sçavans in Paris, the Wienerisches Diarium and other newspapers and periodicals; our focus lay entirely on the preserved autographic letters. ${ }^{16}$ It was not possible within the framework of this study to compile a comprehensive inventory of letters that were printed in contemporary periodicals and books; an expansion into this domain would be interesting for a future project, however. Likewise, it would be an easy task to generate a list of letters that are known to have existed but are not preserved-as evidenced when correspondents began letters by thanking Hell for his previous message.

Like Hell, Weiss also published an annual report, the Observationes astronomicae in observatorio Collegii Academici Societatis Jesu Tyrnaviae in Hungaria habitae (spanning the years 1756-1771), but unlike Hell's Ephemerides, it was a purely local bulletin summarizing observations made at the Trnava observatory. Weiss did, however, publish occasional articles in the Ephemerides, in the Journal Étranger and the Journal des Sçavans in Paris as well as in Bode's Astronomisches Jahrbuch in Berlin. ${ }^{17}$ A comparatively modest number of letters from Weiss's correspondence has survived; a representative selection was edited by Magda Vargha in the early 1990s. ${ }^{18}$ Supplemented by our own archival research, the list of letters available for our study totalled 59 addressed to and 39 written by Weiss. ${ }^{19}$

Fixlmillner published three astronomical books. They include a 134-page determination of the geographical coordinates of Kremsmünster (published in 1765) and two long reports on various astronomical observations made at the monastery's observatory by himself and his assistants, comprising 280 and 556 pages and published in 1776 and 1791 respectively. In contrast to Hell and his Ephemerides, Fixlmillner generally avoided quoting letters in his publications,

the Ephemerides in particular, see László KonTler, The Uses of Knowledge and the Symbolic Map of the Enlightened Monarchy of the Habsburgs. Maximilian Hell as Imperial and Royal Astronomer (1755-1792). In: László Kontler / Anotonella Romano / Silvia Sebastiani / Borbála Zsuzsanna TöRÖк (eds.), Negotiating Knowledge in Early Modern Empires. A Decentered View, Decentering Empires. The Sciences of Heavens, Earth, and Man, c. 1550-1810. Basingstoke - New York 2014, 79-105.

16 The metadata for the entire corpus of letters used for this article are freely available online through UiT's open research data archive, at https://doi.org/10.18710/6JUYEY, accessed 22.02.2019.

17 Aspaas, Maximilianus Hell, 92-93.

18 VARgha, Correspondance, see footnote 11.

19 Metadata for all letters used for this study are available through UiT's open research data archive, at https://doi.org/10.18710/6JUYEY, accessed 22.02.2019. 
referring instead to printed astronomical treatises and reports. ${ }^{20}$ This should not be taken to imply that he lacked "pen-friends", however; in fact, one of his most important contacts was Maximilian Hell. The correspondence between the two men was edited by Ansgar Rabenalt in 1986, a study upon which we relied heavily for the biographical data in the tabular overview below. ${ }^{21}$ For our project, 140 autographic letters addressed to Fixlmillner and 41 written by him were verified. Letters from Fixlmillner were occasionally summarized or quoted in extenso in journals such as Hell's Ephemerides or the Nouveaux Mémoires de l'Académie Royale des Sciences et Belles-Lettres in Berlin. Like in the cases of Hell and Weiss, however, we have not included such letters in the current study.

\section{Visualizing Hell, Weiss and Fixlmillner}

Historians intending to investigate correspondence networks with the help of digital tools can easily find various completed and ongoing projects that provide exemplary case studies as well as tools for visualizing their data. The project "Mapping the Republic of Letters" 22 can be considered the most comprehensive

20 Placidus Fixlmillner, Meridianus Speculae astronomicae Cremifanensis seu Longitudo eius Geographica per magnum illud Solis Deliquium ipsis Calendis Aprilis Anni M.DCC.LXIV. spectatum. Examinatis variorum celebrium Locorum Observationibus accurate investigata atque inventa et adiectis pluribus aliis Spectaculis caelestibus. Styrae 1765; IDEM, Decennium astronomicum continens Observationes praecipuas ab Anno MDCCLXV ad Annum MDCCLXXV in Specula Cremifanensi factas, una cum Calculis. Styrae 1776; IDEM, Acta astronomica Cremifanensia. Divisa in Partes duas, quarum Prior Observationes ab Anno MDCCLXXVI. ad Annum MDCCXCI., earum Calculos et Comparationes cum Tabulis, Posterior vero Exercitationes, seu Enodationes variarum Materiarum astronomicarum complectitur. Styrae 1791. For an overview of Fixlmillner's life and work, see [ANONYmous], Scriptores ordinis S. Benedicti qui 1750-1880 fuerunt in Imperio Austriaco-Hungarico. Vindobona 1881, 95-98.

21 Ansgar Rabenalt, Astronomische Forschung im 18. Jahrhundert in Kremsmünster. Zu den ersten Berechnungen der Bahn des Uranus nach dem Briefwechsel zwischen Placidus Fixlmillner O.S.B. und Maximilian Hell S.J. (1771-1790). In: Mitteilungen des Oberösterreichischen Landesarchivs 15 (1986), 93-216. See also IDEM, Briefe Georg Friedrich Branders, mechanici in Augsburg, an Placidus Fixlmillner OSB, 1. Direktor der Sternwarte von Kremsmünster. Ein Beitrag zur Gründungsgeschichte des "Mathematischen Turmes” von Kremsmünster. In: Studien und Mitteilungen zur Geschichte des Benediktinerordens und seiner Zweige 96 (1985), 144-195. A list of Fixlmillner's correspondence has been assembled and made publicly available on the website of Museum Kremsmünster by P. Amand KrAML, http://www.specula.at/ adv/monat_1702.htm\#Heylling, accessed 22.02.2019. Furthermore, we have received a list with summaries of selected letters made by Marion JANSKY during a visit to Kremsmünster in 2017 (pers. comm., May 2017).

22 http://republicofletters.stanford.edu/, accessed 22.02.2019. 
endeavour to date in terms of visualizing correspondence patterns. It developed Palladio as an open-source tool for modeling networks in timelines, graphs and maps according to commonly applied standards. ${ }^{23}$ The ePistolarium ${ }^{24}$ tool provides online access to a database of seventeenth-century Dutch scholars' letters in which a large corpus of searchable texts is directly connected with various visualization tools and enables complex inquiries, including the mapping of the epistolary connections, too. Nevertheless, as the interim and final results of the present study could not be made accessible online with these tools (neither for collaborators nor for a larger audience), our project has benefitted more from the usage of DARIAH-DE Geo-Browser. ${ }^{25}$

Our aim was to investigate how the existing pieces of information about the three astronomers' correspondence networks could be transformed into a more concise and informative format with the help of digital tools, thereby opening up new fields for analytical inquiries. We began by creating a map enabling us to see the correspondence networks of the three astronomers as separate layers in the same view. ${ }^{26}$ This made the scale and extent of the networks comparable and overlaps between them visible. A more detailed investigation was then carried out on the dataset of each astronomer. First of all, we examined Maximilian Hell's correspondence in order to see how his network changed around 1773. We shaped our dataset according to the requirements of DARIAH-DE Datasheet Editor and, after uploading it, we displayed the data in Geobrowser and divided it into various layers. ${ }^{27}$ We repeated the same process with the data informing about Fixlmillner's and Weiss' epistolary connections. ${ }^{28}$ Finally, we distilled the information obtained from the maps showing the correspondence networks

23 http://hdlab.stanford.edu/palladio/, accessed 22.02.2019.

$24 \mathrm{http}: / /$ ckcc.huygens.knaw.nl/epistolarium/, accessed 22.02.2019.

$25 \mathrm{https} / /$ geobrowser.de.dariah.eu/, accessed 22.02.2019.

$26 \mathrm{http} / / /$ bit.ly/HellFixlmillnerWeiss, accessed 22.02.2019. Unfortunately, the names of the layers disappear in the shareable link and are substituted with ID numbers. Color codes of the map: orange - Hell, purple - Fixlmillner, green - Weiss.

27 The datasheet is available here: http://bit.ly/HellDatasheet. It can be displayed on a map by clicking on "Open Geo-Browser" and it can serve as a base for further inquiries. We created two, online available maps showing the letters separated into recipient (orange) and sender (purple) before and after 1773: http://bit.ly/Hellpre1773, http://bit.ly/Hellpost1773, all accessed 22.02.2019.

28 Fixlmillner's correspondence network in DARIAH-DE Datasheet Editor: http://bit.ly/ FixlmillnerDatasheet. Maps showing Fixlmillner's letters separated into recipient (orange) and sender (purple) before and after 1773: http://bit.ly/Fixlmillnerpre1773, http://bit.ly/ Fixlmillnerpost1773. Weiss' correspondence network in DARIAH-DE Datasheet Editor: http:// bit.ly/WeissDatasheet. Maps showing Fixlmillner's letters separated into recipient (orange) and sender (purple) before and after 1773: http://bit.ly/Weisspre1773, http://bit.ly/Weisspost1773, all accessed 22.02.2019. 
of Hell, Weiss and Fixlmillner before and after 1773 into six printable maps created with QGIS. The starting point, however, was a purely tabular factual overview of the preserved letters from and to the three Habsburg astronomers.

\subsection{Hell's Surviving Correspondence Before and After 1773}

Maximilian Hell received 105 letters between 1757 and 1790; of these, 91 were received between 1757 and 1772 (fifteen years) and 14 between 1776 and 1790 (fourteen years). No incoming letters are known for the period between 1772 and 1776. In terms of geography, he received letters from 26 cities (reduced to 23 after the merging of Schwetzingen with Heidelberg, of Versailles with Paris, and of Baden near Vienna with Vienna) before 1773, but only from three cities after 1776. In the earlier, more intense period, the known/researched letters exhibit an uneven temporal distribution as well: Hell's correspondence as a recipient of letters was most intense during the year 1759, followed by 1761 . For the years 1762, 1765 and 1767-69, there are no surviving letters at all. ${ }^{29}$

Maximilian Hell sent 259 letters between 1757 and 1791. Of these, 148 were sent between 1757 and 1772, four in 1773, and 107 between 1774 and 1791 . His letters were sent to 29 cities before 1773 (27 after the merging of Baden with Vienna and of the Vatican with Rome). The location of the addressee is unknown in two cases: von Condie (1761) and J.E. Nilson (1772). Regarding the temporal distribution, 1761 (the year of one of the aforementioned transits of Venus) stands out with 43 letters. Hell's intensive contact with Paris also seems to have been restricted to a relatively short period of time between 1758 and 1764, again with a peak in 1761. In the period from April 1768 to September 1770, Hell was absent from Vienna, undertaking a grand expedition to observe the 1769 transit of Venus from Vardø on the extreme north-eastern periphery of the Dano-Norwegian realm. This expedition has been researched by several historians, which explains the larger number of letters known to have survived from these years. ${ }^{30}$ No letters are known for the year 1767, however.

Hell's stay in Vardø coincides with an increase in the number of letters written by him. It is interesting to note, however, that it was not the number of letter destinations that increased significantly, but rather the number of addressees. Hell sent letters to seven cities (Copenhagen, Hamburg/Lübeck, Rome, Talvik, Trondheim, Vardø and Vienna), where they reached 19 or 20 recipients-many of whom were not strictly speaking astronomers, but persons involved in the

291757 (11), 1758 (18), 1759 (24), 1760 (1), 1761 (20), 1763 (6), 1764 (1). 1766 (2), 1770 (3), 1771 (4), 1772 (1). We cannot rule out the possibility that Hell's actual correspondence was constant throughout this period. The fragmentary survival of his correspondence is a problem that was difficult to remedy within the framework of this study, however.

301757 (2), 1758 (6), 1759 (7), 1760 (4), 1761 (43), 1762 (4), 1763 (1), 1764 (5), 1765 (2), 1766 (3), 1768 (15), 1769 (29), 1770 (2), 1771 (13), 1772 (12). 
organization of his trip (Bredal/Paus, Eckleff; the Superior General of the Society of Jesus; Gondola; Grambow; Gunnerus; Hagerup; Christian Horrebow; Höller; Mercier; Niebuhr; Nordal; Oeder; Pilgram; Schøller/Schöller; Thott; von Bachoff; von Oettel; von Osten). A few hubs (Copenhagen, Trondheim, Vienna, etc.) in which the majority of recipients were located can thus be identified. Other possible subcategories of the destinations of Hell's letters (e.g. the Baltic region, capitals) can also be identified.

The temporal distribution of the letters during the post- 1773 period is more uniform, with only the year 1781 appearing somewhat more intense with 19 letters. $^{31}$

Tab. 1 Maximilian Hell: number of received and sent letters.

Yellow = secular Catholic; Pink = Catholic bishop; Green = (ex-)Jesuit;

Turquoise = Benedictine; Dark red = Lutheran bishop; Red = lay Lutheran; Teal $=$ Calvinist; Grey $=$ uncertain/not applicable.

\begin{tabular}{|l|l|l|l|l|l|}
\hline Place & $\begin{array}{l}\text { Received } \\
\text { before } \\
\mathbf{1 7 7 3}\end{array}$ & $\begin{array}{l}\text { Sent } \\
\text { before } \\
\mathbf{1 7 7 3}\end{array}$ & $\begin{array}{l}\text { Re- } \\
\text { ceived } \\
\text { after } \\
\mathbf{1 7 7 3}\end{array}$ & $\begin{array}{l}\text { Sent } \\
\text { after } \\
\mathbf{1 7 7 3}\end{array}$ & $\begin{array}{l}\text { Denomination of } \\
\text { correspondent }^{32}\end{array}$ \\
\hline Auxerre & 1 & 0 & 0 & 0 & Trébuchet \\
\hline $\begin{array}{l}\text { Baden near } \\
\text { Vienna }\end{array}$ & 1 & 1 & 0 & 0 & Cassini de Thury \\
\hline Berlin & 0 & 4 & 0 & 13 & Bernoulli, \\
\hline Bologna & 0 & 1 & 0 & 0 & Lambert \\
\hline Bratislava & 2 & 7 & 0 & 0 & Pranotti \\
\hline Buda & 0 & 0 & 0 & 24 & Schumacher \\
\hline Copenhagen & 0 & 15 & 4 & 6 & Pray, Weiss \\
\hline Debrecen & 2 & 1 & 0 & 0 & Bugge, \\
\hline Eger & 0 & 3 & 0 & 26 & Hatvani \\
\hline Florence & 4 & 2 & 0 & 0 & Eszterhazy \\
\hline Göttingen & 1 & 0 & 0 & 2 & Schlözer, \\
\hline Graz & 3 & 0 & 0 & 0 & Kästner \\
\hline
\end{tabular}

311774 (5), 1775 (4), 1776 (8), 1777 (12), 1778 (4), 1779 (9), 1780 (3), 1781 (19), 1782 (12), 1783 (5), 1785 (4), 1786 (2), 1787 (5), 1788 (3), 1789 (5), 1790 (3), 1791 (4).

32 Information regarding denominations was gleaned from readily available biographical lexica such as the online version of Deutsche Biographie (www.deutsche-biographie.de, accessed 22.02.2019). 


\begin{tabular}{|c|c|c|c|c|c|}
\hline Place & $\begin{array}{l}\text { Received } \\
\text { before } \\
1773\end{array}$ & $\begin{array}{l}\text { Sent } \\
\text { before } \\
1773\end{array}$ & $\begin{array}{l}\text { Re- } \\
\text { ceived } \\
\text { after } \\
1773\end{array}$ & $\begin{array}{l}\text { Sent } \\
\text { after } \\
1773\end{array}$ & $\begin{array}{l}\text { Denomination of } \\
\text { correspondent }^{32}\end{array}$ \\
\hline $\begin{array}{l}\text { Hamburg/ } \\
\text { Lübeck }\end{array}$ & 0 & 1 & 0 & 0 & Gondola \\
\hline Heidelberg & 2 & 5 & 0 & 0 & Chr. Mayer \\
\hline Ingolstadt & 4 & 0 & 0 & 0 & Kratz, Zech \\
\hline Innsbruck & 2 & 0 & 0 & 0 & Weinhart \\
\hline Kremsmünster & 2 & 4 & 9 & 19 & Fixlmillner \\
\hline Ljubljana & 0 & 2 & 0 & 0 & Taufferer \\
\hline Madrid & 1 & 2 & 0 & 0 & Rieger \\
\hline Marseille & 0 & 1 & 0 & 0 & Pézenas \\
\hline Milan & 0 & 2 & 0 & 0 & Bovio, Gerra \\
\hline Padua & 1 & 1 & 0 & 0 & Poleni \\
\hline Paris & 16 & 26 & 0 & 0 & $\begin{array}{l}\text { Lacaille, Delisle, } \\
\text { Messier, Lalande, } \\
\text { Huberti, } \\
\text { De Luynes, Jour- } \\
\text { nal des Sçavans }\end{array}$ \\
\hline Passau & 1 & 0 & 0 & 0 & Ritter \\
\hline Pécs & 3 & 0 & 0 & 0 & Hertl \\
\hline Peking & 1 & 0 & 0 & 0 & Hallerstein \\
\hline Prague & 4 & 8 & 0 & 1 & Stepling \\
\hline Przemyśl & 1 & 0 & 0 & 0 & Sendzimir \\
\hline Rome & 0 & 2 & 0 & 0 & $\begin{array}{l}\text { Jesuit Superior } \\
\text { General }\end{array}$ \\
\hline Schwetzingen & 1 & 0 & 0 & 0 & Chr. Mayer \\
\hline Sens & 1 & 0 & 0 & 0 & De Luynes \\
\hline Stockholm & 0 & 10 & 0 & 4 & Wargentin \\
\hline St. Petersburg & 2 & 4 & 0 & 0 & Braun, Müller \\
\hline Talvik & 0 & 5 & 0 & 0 & $\begin{array}{l}\text { Hagerup, } \\
\text { Bredal/Paus } \\
\end{array}$ \\
\hline Tobolsk & 0 & 2 & 0 & 0 & $\begin{array}{l}\text { Chappe } \\
\text { d'Auteroche }\end{array}$ \\
\hline Trnava & 21 & 17 & 1 & 8 & $\begin{array}{l}\text { Weiss, Kaprinai, } \\
\text { Katona }\end{array}$ \\
\hline
\end{tabular}




\begin{tabular}{|c|c|c|c|c|c|}
\hline Place & $\begin{array}{l}\text { Received } \\
\text { before } \\
1773\end{array}$ & $\begin{array}{l}\text { Sent } \\
\text { before } \\
1773\end{array}$ & $\begin{array}{l}\text { Re- } \\
\text { ceived } \\
\text { after } \\
1773 \\
\end{array}$ & $\begin{array}{l}\text { Sent } \\
\text { after } \\
1773\end{array}$ & $\begin{array}{l}\text { Denomination of } \\
\text { correspondent }^{32}\end{array}$ \\
\hline Trondheim & 0 & 9 & 0 & 0 & $\begin{array}{l}\text { Gunnerus, } \\
\text { Nordal, } \\
\text { von der Osten, } \\
\text { Schöller, } \\
\text { Grambow } \\
\end{array}$ \\
\hline Turku & 0 & 0 & 0 & 1 & Planman \\
\hline Vard $\varnothing$ & 0 & 2 & 0 & 0 & Eckleff \\
\hline Vatican & 0 & 1 & 0 & 0 & The Pope \\
\hline Versailles & 1 & 0 & 0 & 0 & De Luynes \\
\hline Wetzlas & 1 & 0 & 0 & 0 & Zum Schlug \\
\hline Vienna & 0 & 11 & 0 & 1 & $\begin{array}{l}\text { Von Oëttel, } \\
\text { Höller, Bachoff, } \\
\text { Pilgram, Kaiser- } \\
\text { liche Hofkammer }\end{array}$ \\
\hline Würzburg & 12 & 1 & 0 & 0 & Huberti \\
\hline Total & 91 & 151 & 14 & 105 & \\
\hline
\end{tabular}

\subsection{Weiss's Surviving Correspondence Before and After 1773}

Weiss sent 39 letters, 22 before (or during) and 17 after 1773 . They were addressed to only four people. The contact with Johann III Bernoulli in Berlin became more intense after 1773 (8 letters). The 18 letters sent to Maximilian Hell in Vienna, the most numerous group of letters in the pre-1773 era, were written between 1757 and 1761. Weiss's contact with Pehr Wilhelm Wargentin (in Stockholm) maintained a steady pace with 9 letters each during the pre- and post-1773 periods. Placidus Fixlmillner (in Kremsmünster) received only one letter in 1776.

Weiss received 59 letters: 27 between 1750 and 1773, and 30 between 1774 and 1784. His contact with Berlin, Mannheim and Trnava became more intense after 1773, while the number of letters received from Paris decreased. The contact with Stockholm seems to have been constant in terms of the number of received letters. 


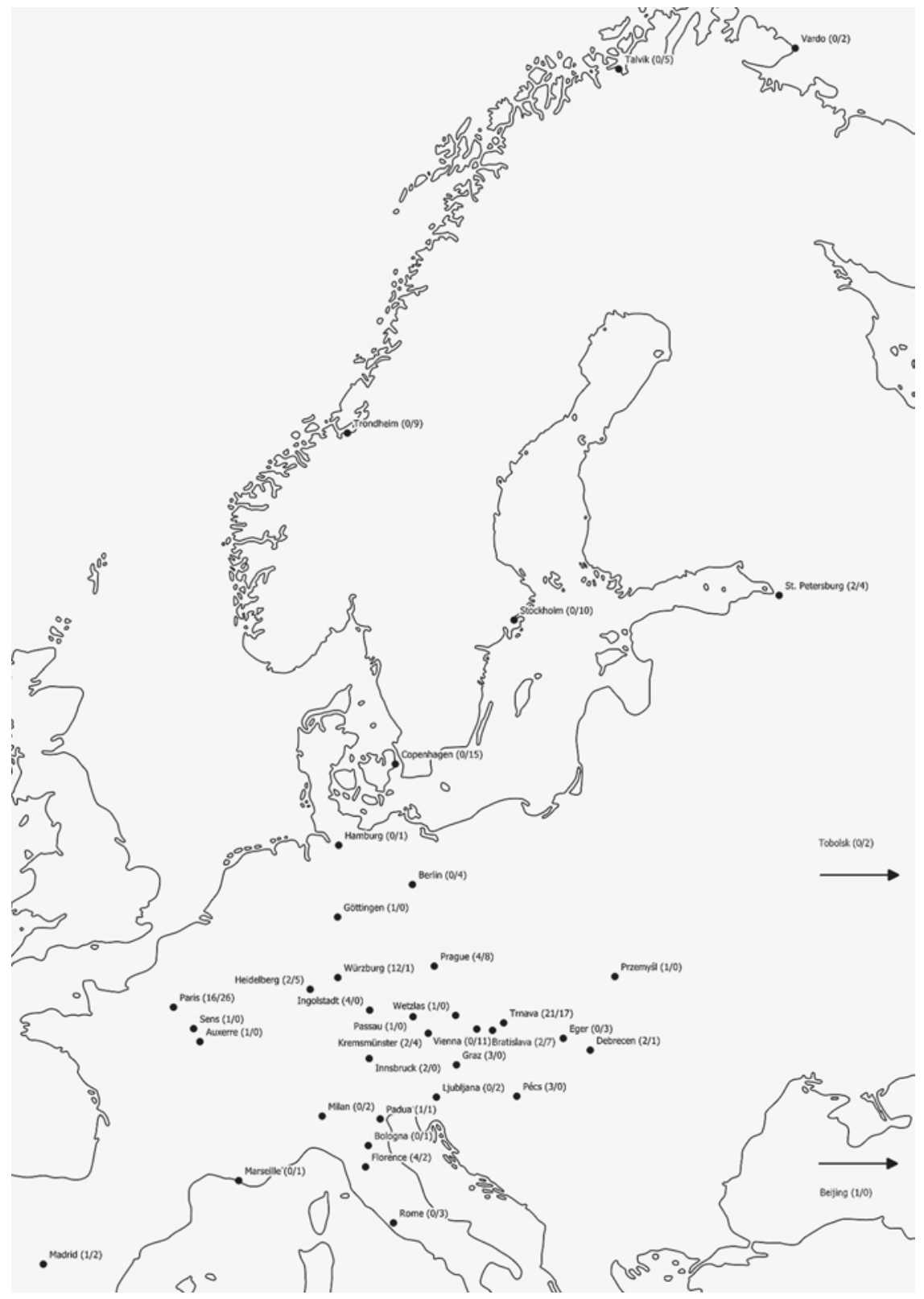

Fig. 1 Maximilian Hell: number of received and sent letters before 1773 . 


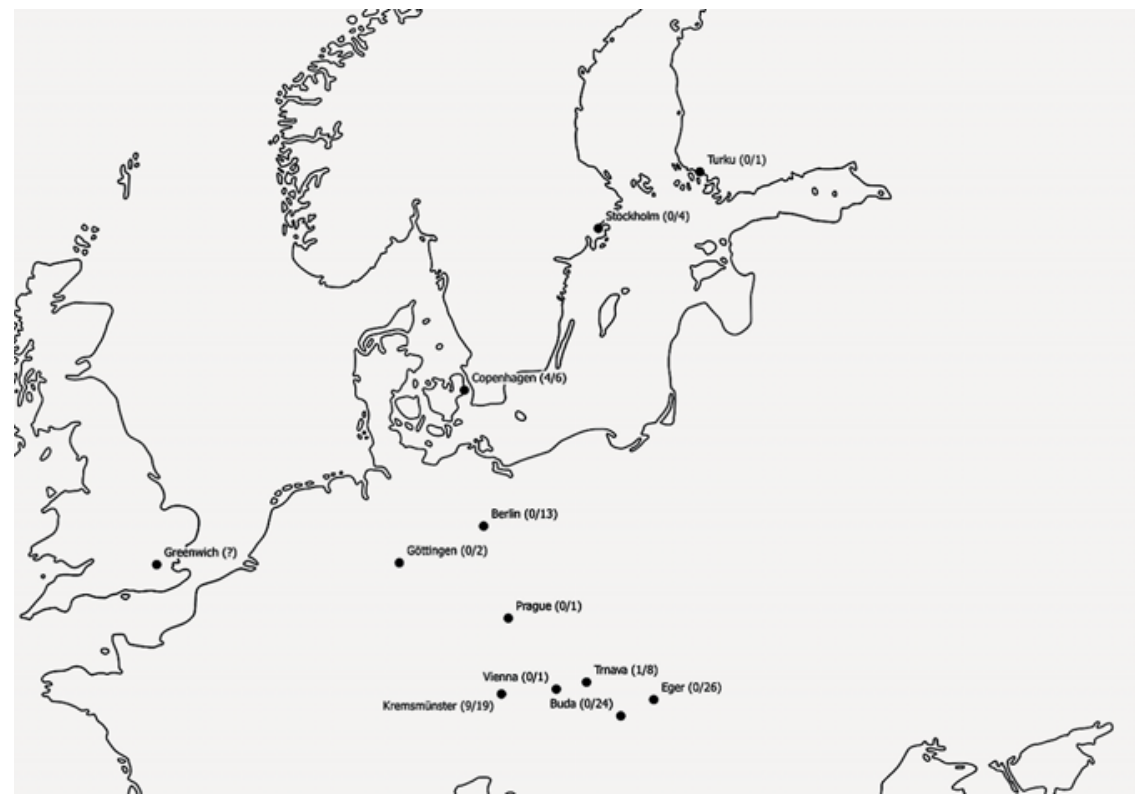

Fig. 2 Maximilian Hell: number of received and sent letters after 1773.

\subsection{Fixlmillner's Surviving Correspondence Before and After $\mathbf{1 7 7 3}$}

Fixlmillner received 40 letters from 9 cities between 1755/1764 and 1773, with the most intense year being 1771 with 11 letters. ${ }^{33}$ He received 104 letters from 17 cities after 1773 (until 1791). The most intense years of this period were the mid-1780s. ${ }^{34}$

Fixlmillner sent 41 letters, of which 4 are undated and only 5 were written before 1773. Two of the latter were addressed to Jérôme de Lalande (1768) and the Jesuit Christian Rieger (1770) in Paris and three to Cajetan Jungwirth (1770-1771) in Berlin. After 1773, the destination is unknown in two cases. During this period, letters were sent to 9 cities, among which Berlin and Paris were still the most important. The addressees were often the same (around 10 to 12 ) people, occasionally appearing at multiple locations.

331755 (1), 1762 (2), 1764 (2), 1766 (5), 1767 (2), 1768 (4), 1769 (3), 1770 (3), 1771 (11), 1772 (7), $1773(1)$.

341773 (1), 1774 (1), 1775 (1), 1776 (8), 1779 (3), 1780 (4), 1781 (5), 1782 (9), 1783 (4), 1784 (5), 1785 (10), 1786 (10), 1787 (11), 1788 (7), 1789 (7), 1790 (6), 1791 (3), 1792 (1). 
Tab. 2 Ferenc Weiss: number of received and sent letters.

Yellow = secular Catholic; Pink = Catholic bishop; Green = (ex-)Jesuit;

Turquoise = Benedictine; Dark red = Lutheran bishop; Red = lay Lutheran; Teal = Calvinist; Grey $=$ uncertain/not applicable.

\begin{tabular}{|l|l|l|l|l|l|}
\hline Place & $\begin{array}{l}\text { Received } \\
\text { before } \\
\mathbf{1 7 7 3}\end{array}$ & $\begin{array}{l}\text { Sent } \\
\text { before } \\
\mathbf{1 7 7 3}\end{array}$ & $\begin{array}{l}\text { Re- } \\
\text { ceived } \\
\text { after } \\
\mathbf{1 7 7 3}\end{array}$ & $\begin{array}{l}\text { Sent } \\
\text { after } \\
\mathbf{1 7 7 3}\end{array}$ & $\begin{array}{l}\text { Denomination of } \\
\text { correspondent }\end{array}$ \\
\hline Berlin & 1 & 1 & 5 & 7 & Bernoulli \\
\hline Graz & 2 & 0 & 1 & 0 & Scherffer \\
\hline Kremsmünster & 0 & 0 & 0 & 1 & Fixlmillner \\
\hline Madrid & 1 & 0 & 0 & 0 & Rieger \\
\hline Mannheim & 1 & 0 & 6 & 0 & Chr. Mayer, \\
\hline Maur & 1 & 0 & 0 & 0 & Schmerffer \\
\hline Milan & 0 & 0 & 1 & 0 & Cesaris \\
\hline Paris & 12 & 0 & 4 & 0 & Delisle, Lacaille, \\
& & & & Lalande, Clairaut \\
\hline Stockholm & 6 & 9 & 7 & 9 & Wargentin \\
\hline Trnava & 0 & 0 & 7 & 0 & Taucher \\
\hline Wien & 2 & 18 & 1 & 0 & Scherffer, Hell \\
\hline Würzburg & 1 & 0 & 0 & 0 & Huberti \\
\hline Total & 27 & 28 & 32 & 17 & \\
\hline
\end{tabular}

\section{Avenues for Further Research: Digital Humanities and Traditional Hermeneutics}

The study of correspondences is a well-established method in the history of science, and the traditional approach entails systematic reading of substantial amounts of correspondence with the aim of excerpting key expressions and obtain a general impression of features characteristic of a particular period, project or character. ${ }^{35} \mathrm{~A}$ basic problem is that this is a very time-consuming task-and with often hundreds of extant letters, the risk of becoming too immersed in details and losing sight of the overall picture is manifest. Illustrations

35 To cite just two excellent examples: Sven Widmalm, A Commerce of Letters. Astronomical Communication in the $18^{\text {th }}$ Century. In: Science Studies 5:2 (1992), 43-58; Georges DulaC, La vie académique à Saint-Pétersbourg vers 1770, d’après la correspondence entre J.A. Euler et Formey. In: Daniel-Odon Hurel / Gérard LAudin (eds.), Académies et sociétés savantes en Europe (1650-1800). Paris - Geneva 2000, 221-263. 


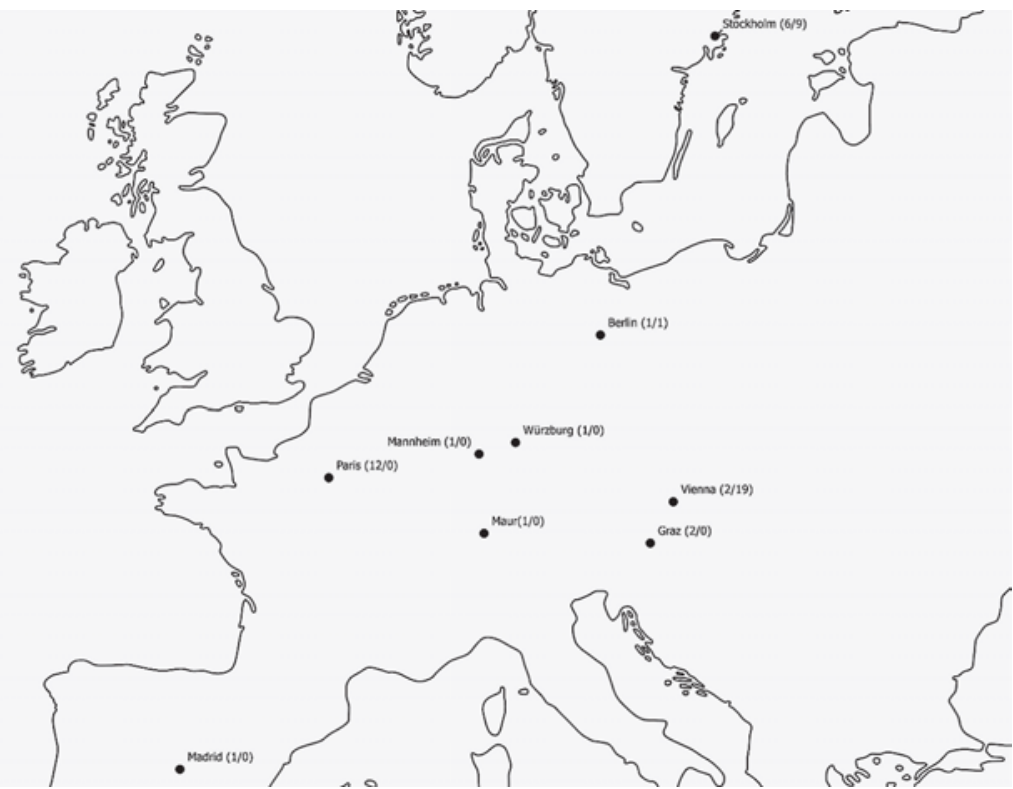

Fig. 3 Ferenc Weiss: number of received and sent letters before 1773.

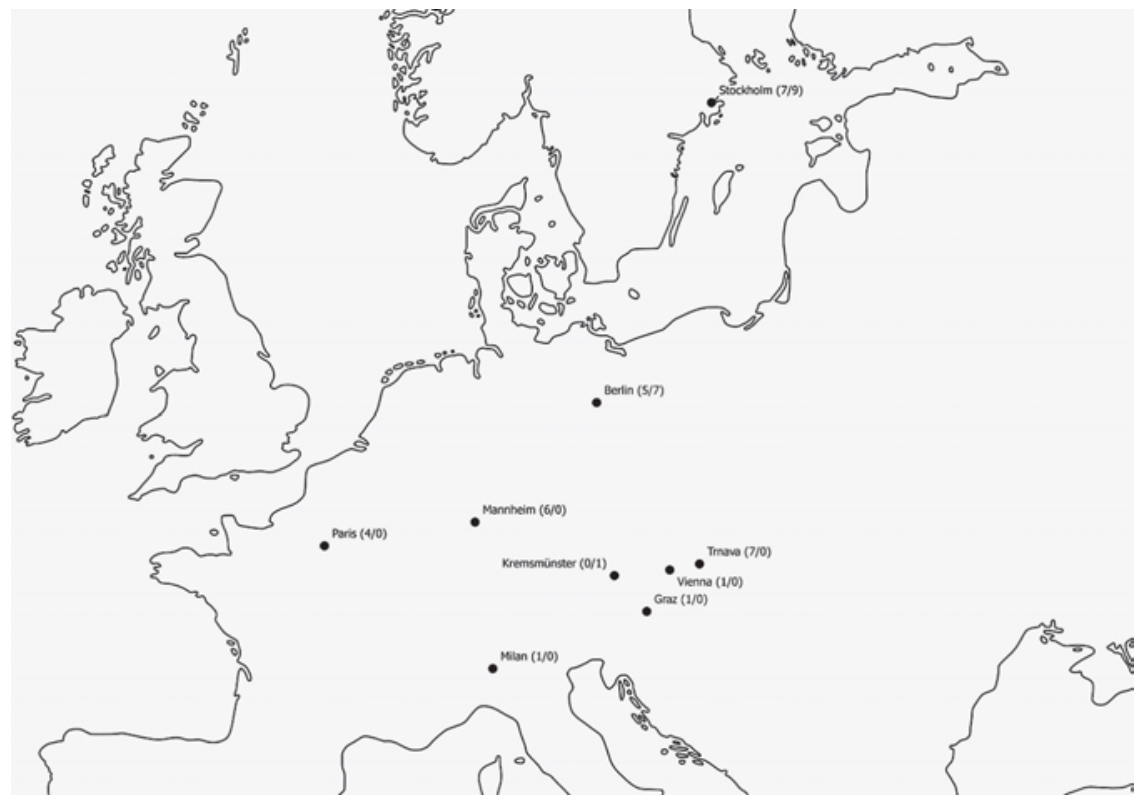

Fig. 4 Ferenc Weiss: number of received and sent letters after 1773. 
Tab. 3 Placidus Fixlmillner: number of received and sent letters.

Yellow = secular Catholic; Pink = Catholic bishop; Bright Green = (ex-)Jesuit;

Turquoise $=$ Benedictine; Dark Yellow $=$ other Catholic order; Dark Red = Lutheran bishop; Red = lay Lutheran; Teal = Calvinist; Violet = Anglican; Grey = uncertain/not applicable.

\begin{tabular}{|c|c|c|c|c|c|}
\hline Place & $\begin{array}{l}\text { Received } \\
\text { before } \\
1773\end{array}$ & $\begin{array}{l}\text { Sent } \\
\text { before } \\
1773\end{array}$ & $\begin{array}{l}\text { Re- } \\
\text { ceived } \\
\text { after } \\
1773\end{array}$ & $\begin{array}{l}\text { Sent } \\
\text { after } \\
1773\end{array}$ & $\begin{array}{l}\text { Denomination of } \\
\text { correspondent }\end{array}$ \\
\hline Augsburg & 21 & 0 & 3 & 0 & Casatti \\
\hline Berlin & 0 & 3 & 37 & 14 & Bernoulli, Bode \\
\hline Ensdorf & 1 & 0 & 0 & 0 & Desing \\
\hline Gleink & 0 & 0 & 2 & 2 & Holmayr \\
\hline Irsee & 3 & 0 & 3 & 1 & Dobler \\
\hline London & 0 & 0 & 1 & 0 & Maskelyne \\
\hline Mannheim & 0 & 0 & 3 & 0 & Chr. Mayer \\
\hline Ober-Ensingen & 0 & 0 & 2 & 2 & Wurm \\
\hline Ofterdingen & 0 & 0 & 1 & 0 & Wurm \\
\hline Paris & 1 & 2 & 15 & 5 & $\begin{array}{l}\text { Lalande, Jeaurat } \\
\text { Cassini }\end{array}$ \\
\hline Polling & 0 & 0 & 1 & 0 & Schlögl \\
\hline Prague & 0 & 0 & 6 & 1 & Strnadt \\
\hline Passau & 3 & 0 & 0 & 0 & Chr. Rieger \\
\hline Regensburg & 0 & 0 & 1 & 0 & Gerstner \\
\hline Rome & 2 & 0 & 1 & 0 & Gentili \\
\hline Rott & 0 & 0 & 2 & 0 & Sutor, Weigl \\
\hline Sonthofen & 0 & 0 & 2 & 0 & Ammann \\
\hline Salzburg & 1 & 0 & 0 & 3 & Jungwirth \\
\hline St. Pölten & 1 & 0 & 0 & 0 & Heylling \\
\hline Trnava & 0 & 0 & 1 & 0 & Weiss \\
\hline Vienna & 7 & 0 & 23 & 4 & $\begin{array}{l}\text { Chr. Rieger, } \\
\text { Pilgram, } \\
\text { Liesganig, Hell, } \\
\text { Triesnecker, } \\
\text { Pasterwiz } \\
\end{array}$ \\
\hline Total & 40 & 5 & 104 & 32 & \\
\hline
\end{tabular}




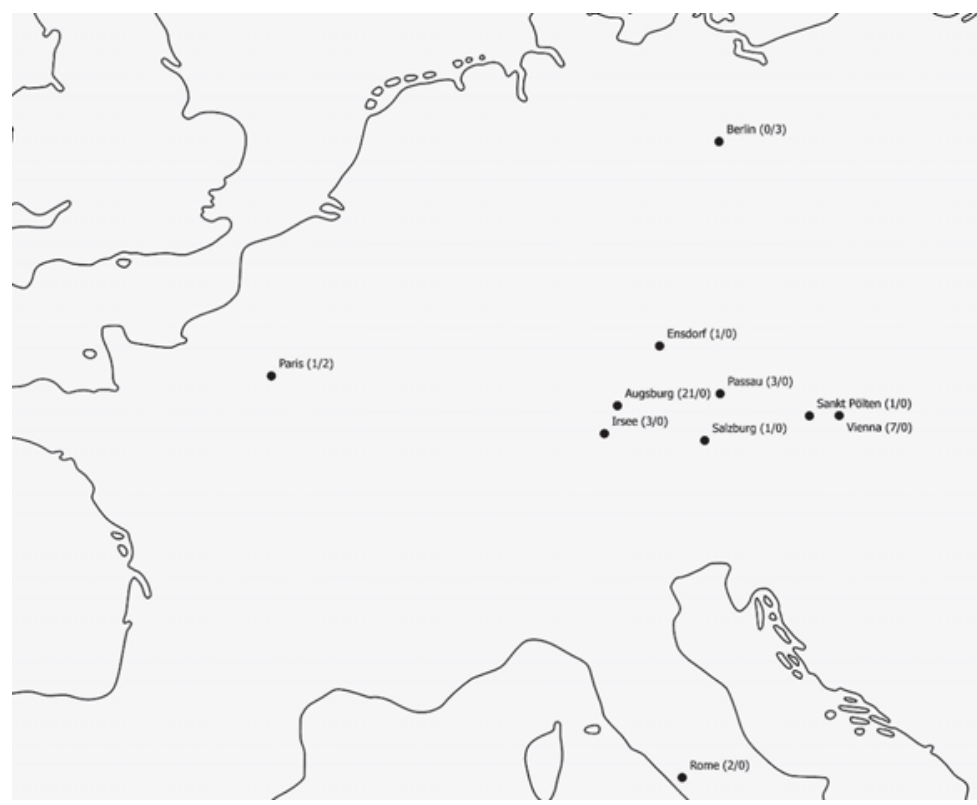

Fig. 5 Placidus Fixlmillner: number of received and sent letters before 1773.

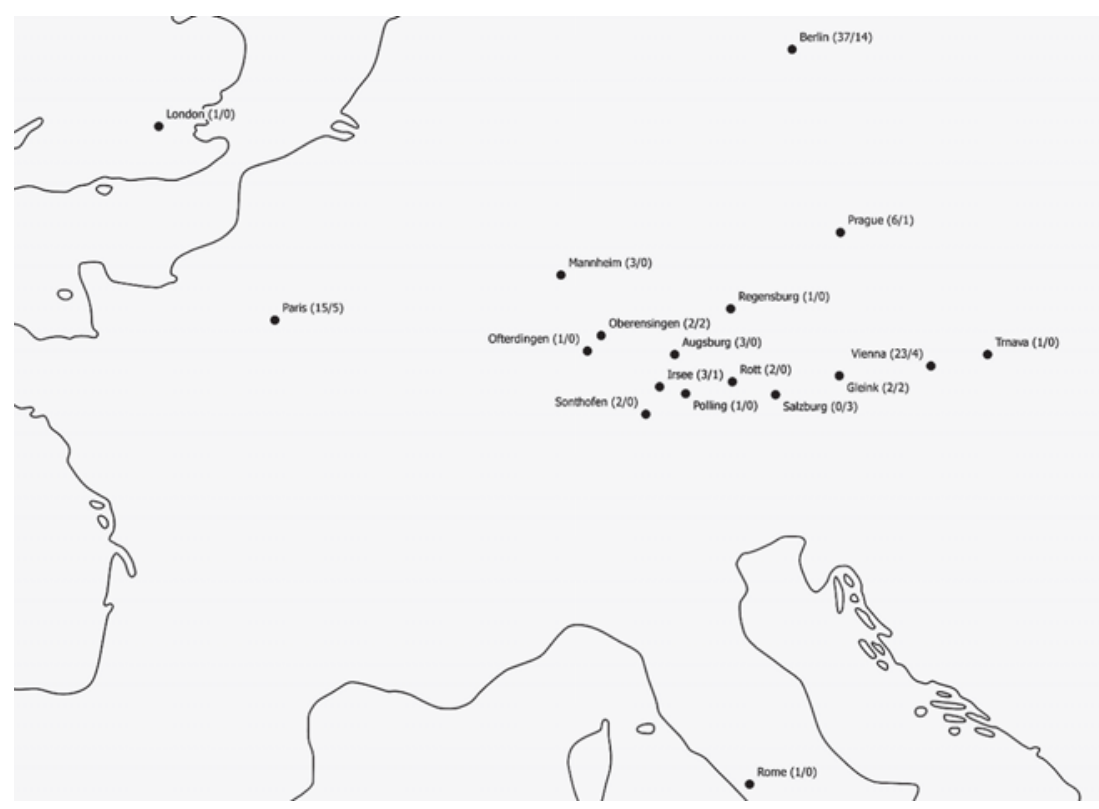

Fig. 6 Placidus Fixlmillner: number of received and sent letters after 1773. 
are sometimes used in such historiographical work, but usually only as a dispensable, extraneous feature pasted in after the actual hermeneutical analysis has been completed.

In our experiment, we used systematizations and visualizations of metadata (letter written by person $x$ at location $a$, addressed to person $y$ at location $b$ ) as a starting point. The idea was to use these visualizations of correspondence networks as a means to help speed up the hermeneutical process. While the number of preserved letters turned out to be too small and fragmentary to place specific emphasis on quantitative aspects within the project, the systematization did help to direct our attention towards gaps that may be indicative of actual ruptures of contact. László Kontler's recent study of Hell's Ephemerides points out a strong presence of French astronomy in the journal up until about 1773 that disappears soon thereafter. ${ }^{36}$ This coincides with our data. French astronomers virtually disappear from the correspondence of both Hell and Weiss after the suppression of the Society of Jesus. France, a leading agent in the ideological battle against "Jesuit learning", dwindled away as an ally in the quest for corresponding observations. For the Benedictine Fixlmillner, such a pattern is barely distinguishable or at least less pronounced. Their strong and stable contacts with Berlin and Stockholm prove that both Weiss and Hell maintained a transnational and transconfessional correspondence after 1773; it merely shifted away from France. There may also have been other, more personal reasons for this: After returning to Vienna from his Venus transit expedition in Denmark and Norway, Hell soon found himself engaged in a fierce battle to defend the reliability of his observations made during the trip-as well as his own calculations of the Sun-Earth distance that used his own observations as a crucial set of data along with corresponding observations made in other parts of the world. During this controversy, Hell targeted a leading network figure in French astronomy in particular: Jerôme de Lalande. ${ }^{37}$ Fixlmillner remained in contact with both Hell and Lalande after the dispute, in which he played no part. As a former Jesuit associated closely with Hell and his plight, Weiss may have been partially affected. A careful reading of the surviving letters from this particularly heated period of scientific controversy paired with religious upheaval would be necessary to test this hypothesis, however-and the maps of the correspondence networks might have the potential to point the scientific glance in the right direction in terms of which letters to study.

36 Kontler, Uses.

37 Per Pippin AspaAs, Le Père Jésuite Maximilien Hell et ses relations avec Lalande. In: Guy Boistel / Jérôme LAmy / Colette LeLAy (eds.), Jérôme Lalande (1732-1807). Une trajectoire scientifique. Rennes 2010, 129-148. 
The datasets and visualizations presented above are no more than an outline of how such visualizations might potentially be used. Full-scale scrutiny would require much larger datasets in order to rule out individual and local contingencies as well as the problem of the fragmentary preservation of source materials. As with any historical inquiry, it is important to consider the source materials underpinning the map. Ideally, studies should be performed on the correspondence networks of a representative selection of astronomers from various religious denominations whose professional correspondences remain entirely (or at least largely) intact. For such a large-scale project, one can safely assume that visualization tools would have the potential to aid historians in their endeavour to recognize various trends and acute ruptures of contact. Two characters situated on the fringes of this study, but simultaneously at the centre of events in eighteenth-century astronomy, come to mind.

In 1764, Johann III Bernoulli (1744-1807) of the famous Basel-based family of natural philosophers and mathematicians was inducted into the Prussian Academy of Sciences in Berlin, ${ }^{38}$ where he was soon appointed Astronomer Royal and director of the academy's observatory. In this capacity, he made his mark as a disseminator of scientific news from all over Europe and beyond. His Lettres Astronomiques (1771), written during a Grand Tour of Britain and Europe in 1768/69, as well as the journals Recueil pour les Astronomes (1771-1776) and Nouvelles Littéraires des divers pays (1776-1779) with their concomitant "Necrologues" and "Listes des astronomes actuellement vivans" are invaluable sources for historians of science. From the early 1780s onwards, Johann III published more frequently in German and extended his range of interest far beyond astronomy proper. Particularly noteworthy are his multi-volume Sammlung kurzer Reisebeschreibungen und anderer zur Erweiterung der Länder- und Menschenkenntniss dienender Nachrichten (1781-86) and the Leipziger Magazin für reine und angewandte Mathematik (with K. F. Hindenburg, 1786-88). Bernoulli often quoted letters in the periodicals he edited. In the same way that a letter listing astronomical observations and sent to Hell in Vienna might end up being printed in the Ephemerides, there are numerous examples of letters from Bernoulli's correspondents that were published in his various periodicals. A fundamental difference, however, is that in Bernoulli's case, virtually every letter is preserved intact. His entire incoming correspondence is well organized and kept at the Basel University Library. If one wished to address the question

38 Part of the text of this paragraph has been published earlier in a book review for the yearbook xviii.ch. See Per Pippin Aspaas / Simone Dumont / Jean-Claude Pecker (eds.), Jérôme Lalande, Mission à Berlin: Lettres à Jean III Bernoulli et à Elert Bode (Paris 2014). In: xviii.ch. Jahrbuch der Schweizerischen Gesellschaft für die Erforschung des 18. Jahrhunderts 8 (2017), 107-109 (extended manuscript version available at http://hdl.handle.net/10037/12581, accessed 22.02.2019.) 
of correspondence before and after 1773 for a character outside of Catholic Europe whose family background was Huguenot (Calvinist), Bernoulli would be an obvious candidate. His dedicated focus on astronomy proper waned over the course of the 1780s, however, and the parts of his correspondence dealing with other topics (history, geography, physics, etc.) would therefore have to be manually excluded so as to obtain a representative picture of his "corresponding observations" of astronomical content. ${ }^{39}$

In Stockholm, Bernoulli's counterpart Pehr Wilhelm Wargentin (1717-1783), secretary of the Royal Swedish Academy of Sciences and director of the Stockholm observatory since its construction in the early 1750s, left behind a similarly vast correspondence. His own research articles focused on the moons of Jupiter; corresponding observations of this particularly intriguing phenomenon made up much of the content of his incoming letters, particularly from foreign correspondents. In his role of secretary of the Academy, he edited not only the official Swedish Almanak but also the scientific journal Kungliga Vetenskaps Academiens Handlingar, with four issues appearing per year during the entire timespan from 1750 until Wargentin's death in $1783 .{ }^{40}$ Wargentin is a special case when it comes to outgoing letters as well: He kept a record of his letters to foreign correspondents, meaning that this part of his astronomical correspondence can easily be reconstructed on a metadata level (addressed to whom, where and when) despite the loss of many letters. All incoming letters to Wargentin are kept at the Centre for the History of Science of the Royal Swedish Academy of Science in Stockholm. A similar, purely astronomical subset as described above in regard to Johann III Bernoulli could be generated for Wargentin's correspondence. ${ }^{41}$

Entering the relevant metadata from Wargentin and Bernoulli into an Excel sheet (or another data program) would be an obvious place to start. However, such raw data barely provide any information beyond the purely quantitative. In our attempt to detect patterns of transdenominational communication, we

39 During an archival visit to Basel in February-March 2017, P.P. Aspaas photocopied the entire astronomical correspondence of Johann III Bernoulli. There is work still to be done in terms of metadata plotting and organizing before an analysis of this vast corpus can be undertaken.

40 All issues were translated into German and published in Hamburg and Leipzig as well: Der Königl. Schwedischen Akademie der Wissenschaften Abhandlungen aus der Naturlehre, Haushaltungskunst und Mechanik [...]. Aus dem Schwedischen übersetzt. While there are a fair number of astronomical articles in this series, the actual observations that are included were mostly made on Swedish soil.

41 P.P. Aspaas visited this archive on two occasions in October 2006 and December 2017. Another visit and substantial organizing of metadata will be needed to prepare a comprehensive tabular overview and visualization of Wargentin's astronomical correspondence network. 
need to tag the various correspondents according to their religious denomination and move on from this basic data to visualization. The most standard visualization tool is the "frozen" geographical map, and it is by and large what distinguishes most well-known studies of early modern correspondences such as the Mapping the Republic of Letters project. But by now, Digital Humanities has moved further along. Dynamic visualization tools are more frequently used for the entire research process; a simple "frozen" view is often misleading. Video clips visualizing trends over time (in other words, combining the temporal and the spatial) often reveal more than words accompanied by still pictures encompassing multiple years, which is what we have presented here. Venturing into the terrain of the purely optical entails the risk of oversimplifying complex historical contexts and processes, however. As humanists with an interest in the digital, we must nevertheless remain true to the assets of traditional hermeneutical analysis. Digital tools should be employed as an aid for the humanities, not as a substitute for careful inquiry. There are thus essentially two ways in which to expand this research: One is to supplement the tabular overview and accompanying visualizations with additional data, such as information on letters whose originals are missing but which can be verified to have existed; another is to actually read the letters and see whether the story that can only be glimpsed through the tabular overviews and visualizations has some substance to it. 
Per Pippin Aspaas, Katalin Pataki

Did Astronomy Constitute a Denominationally Neutral Space within the Republic of Letters?

\title{
Zusammenfassung:
}

Zahlreiche astronomische Observatorien wurden während des achtzehnten Jahrhunderts in ganz Europa eingerichtet, wodurch Astronomie zu einem eigenen Teilfeld der Gelehrtenrepublik wurde. Man könnte behaupten, dass Astronomie um die Jahrhundertmitte einen konfessionell neutralen Raum bildete und sich zu einer wissenschaftlichen Disziplin im modernen Sinn entwickelte. Jesuiten, Benediktiner, Lutheraner, Anglikaner, Kalvinisten - alle beteiligten sich an einem regen Austausch „korrespondierender Beobachtungen“, der ebenso transnational wie transkonfessionell war. Doch welche Folgen für hatten einschneidende Ereignisse wie etwa die Auflösung der Gesellschaft Jesu 1773 für die entsprechenden Korrespondenznetzwerke? In diesem Beitrag experimentieren wir mit Hilfe von Visualisierungswerkzeugen, um möglichen Wirkungen der Auflösung des Jesuitenordens 1773 nachzugehen. Unser Fallbeispiel ist die erhaltene Arbeitskorrespondenz dreier habsburgischer Astronomen - Maximilian Hell SJ in Wien, Ferenc Weiss SJ in Trnava/Budapest, und Placidus Fixlmillner OSB in Kremsmünster.

\begin{abstract}
:
Numerous astronomical observatories were established across Europe over the course of the eighteenth century, rendering astronomy a distinct sub-branch of the Republic of Letters. Arguably, by the mid eighteenth century astronomy functioned as a denominationally neutral space and constituted a scientific discipline in the modern sense. Jesuits, Benedictines, Lutherans, Anglicans, Calvinists - all engaged in a fruitful exchange of „corresponding observations“ that was both transnational and transconfessional. But what effect, if any, did dramatic turns of events, such as the universal dissolution of the Society of Jesus in 1773 , have on their correspondence networks? In this article, we experiment with the use of visualization tools to trace possible effects of the 1773 dissolution of the Jesuit order. Our test case is the surviving professional correspondence of three Habsburg astronomers - Maximilian Hell SJ in Vienna, Ferenc Weiss SJ in Trnava/Budapest, and Placidus Fixlmillner OSB in Kremsmünster.
\end{abstract}




\section{Autor*innenverzeichnis}

\section{Per Pippin Aspaas}

University Library, University of Tromsø - The Arctic University of Norway Postboks 6050 Langnes, 9037 Tromsø, Norwegen

per.pippin.aspaas@uit.no

\section{Stefan Ehrenpreis}

Universität Innsbruck - Institut für Institut für Geschichtswissenschaften und Europäische Ethnologie

Innrain 52d, 6020 Innsbruck, Österreich

stefan.ehrenpreis@uibk.ac.at

\section{Patrick Fiska}

Österreichische Akademie der Wissenschaften - Institut für Kulturgeschichte der Antike

Hollandstraße 11-13, 1020 Wien, Österreich

patrick.fiska@univie.ac.at

\section{Anna Frasca-Rath}

Universität Wien - Institut für Kunstgeschichte

Spitalgasse 2, 1090 Wien, Österreich

anna.sophie.rath@univie.ac.at

\section{Doris Gruber}

Österreichische Akademie der Wissenschaften - Institut für Neuzeit- und Zeitgeschichtsforschung

Hollandstraße 11-13, 1020 Wien, Österreich

doris.gruber@oeaw.ac.at

\section{Mikkel Munthe Jensen}

Max Weber Centre for Advanced Cultural and Social Studies

Universität Erfurt - Forschungszentrum Gotha

Schloss Friedenstein, 99867 Gotha, Deutschland

Mikkel.Jensen@uni-erfurt.de 


\section{Dario Kampkaspar}

Österreichische Akademie der Wissenschaften - Austrian Centre for Digital Humanities (ACDH)

Sonnenfelsgasse 19, 1010 Wien, Österreich

dario.kampkaspar@oeaw.ac.at

\section{Klemens Kaps}

Johannes-Kepler-Universität Linz - Institut für Neuere Geschichte und Zeitgeschichte

Altenberger Straße 69, 4040 Linz, Österreich

klemens.kaps@jku.at

\section{Stephan Kurz}

Österreichische Akademie der Wissenschaften - Institut für Neuzeit- und Zeitgeschichtsforschung

Hollandstraße 11-13, 1020 Wien, Österreich

stephan.kurz@oeaw.ac.at

\section{Kolja Lichy}

Universität Gießen - Osteuropäische Geschichte

Otto-Behaghel-Strasse 10 D, 35394 Gießen, Deutschland

Kolja.Lichy@geschichte.uni-giessen.de

\section{Elisabeth Lobenwein}

Alpen-Adria-Universität Klagenfurt - Institut für Geschichte Universitätsstraße 65-67, 9020 Klagenfurt, Österreich elisabeth.lobenwein@aau.at

\section{Katalin Pataki}

Central European University, Budapest

Nador u. 9, 1051 Budapest, Ungarn

patakikatalin@gmail.com

\section{Marco Quaggiotto}

Politecnico di Milano

Piazza Leonardo da Vinci 32, 20133 Milano, Italien

marcoq@gmail.com 


\section{Claudia Resch}

Österreichische Akademie der Wissenschaften - Austrian Centre for Digital Humanities (ACDH)

Sonnenfelsgasse 19, 1010 Wien, Österreich

claudia.resch@oeaw.ac.at

\section{Marion Romberg}

Österreichische Akademie der Wissenschaften - Institut für Neuzeit- und Zeitgeschichtsforschung

Hollandstraße 11-13, 1020 Wien, Österreich

marion.romberg@oeaw.ac.at

\section{Karin Schneider}

Österreichische Akademie der Wissenschaften - Institut für Neuzeit- und Zeitgeschichtsforschung

Hollandstraße 11-13, 1020 Wien, Österreich

karin.schneider@oeaw.ac.at

\section{Jonathan Singerton}

Österreichische Akademie der Wissenschaften - Institut für Neuzeit- und Zeitgeschichtsforschung

Hollandstraße 11-13, 1020 Wien, Österreich

jonathan.singerton@oeaw.ac.at

\section{Arno Strohmeyer}

Österreichische Akademie der Wissenschaften - Institut für Neuzeit- und Zeitgeschichtsforschung

Hollandstraße 11-13, 1020 Wien, Österreich

arno.strohmeyer@oeaw.ac.at

\section{Thomas Wallnig}

Universität Wien - Institut für Geschichte

Universitätsring 1, 1010 Wien, Österreich

thomas.wallnig@univie.ac.at

\section{Joëlle Weis}

University of Luxemburg - Institute for History

11 Porte des Sciences, L-4366 Esch-sur-Alzette, Luxemburg joelleweis@gmail.com 